\title{
NGF Induces the Expression of the VGF Gene through a cAMP Response Element
}

\author{
Robert J. Hawley, Renate J. Scheibe, and John A. Wagner \\ Department of Biological Chemistry and Molecular Pharmacology, Harvard Medical School and Division of Pediatric \\ Oncology, Dana-Farber Cancer Institute, Boston, Massachusetts 02115
}

\begin{abstract}
NGF is a peptide growth factor that plays a key role in the differentiation and survival of neurons in both the PNS and CNS. NGF acts through both transcription-dependent and transcription-independent mechanisms to regulate the differentiation of PC12 cells. To better understand the regulation of gene expression by NGF, we have defined a cisacting sequence that is immediately upstream of the transcription start site of the VGF (a2/NGF33.1) gene that is required for induction by NGF. Within this sequence is a consensus cAMP response element (CRE) embedded in a 14 base pair palindrome. Mutations in this CRE eliminate induction of the VGF gene both by NGF and by agents that act via CAMP. Although this sequence confers transcriptional induction by both NGF and CAMP, it is not sufficient to allow induction by epidermal growth factor, acidic or basic fibroblast growth factor, or phorbol 12-myristate 13-acetate (PMA). Thus, this sequence defines an element that is selectively activated by NGF and CAMP. Promoter fragments from the VGF gene that include the core CRE efficiently bind the inducible transcription factor CREB, while fragments bearing mutations that eliminate NGF and CAMP inducibility fail to do so.
\end{abstract}

Sequence comparisons and hybridization studies indicate that there are at least two alternatively spliced forms of VGF mRNA, and the accumulation of both of these forms is similarly regulated by NGF and CAMP.

NGF is a target-derived polypeptide growth factor that is essential for the survival, development, and differentiation of specific classes of peripheral and central neurons (Levi-Montalcini and Angeletti, 1968; Thoenen and Barde, 1980; Springer, 1988). NGF is known to bind to both low-affinity and high-affinity cell surface receptors (Sutter et al., 1979), and one component of the NGF receptor has been cloned and extensively studied (Bothwell, 1991; Chao, 1991). Recently it has been shown that the protein encoded by the $t r k$ proto-oncogene, a tyrosine kinase expressed in neurons of the sensory, spinal, and cranial ganglia, is a component of the NGF receptor (Martin-Zanca et al., 1990;

Received Nov. 7, 1991; revised Jan. 28, 1992; accepted Jan. 31, 1992.

We thank Marc Montminy for providing $\alpha 244$ anti-CREB antiserum, and Cindy Miranti and Mike Greenberg for providing baculovirus-expressed CREB. We also thank Chris DeFranco for his advice and assistance, and John Licht, John Boylan, and David Ginty for comments on the manuscript. This work was supported by NIH Grants CA22427, EY06454, and CA40929. R.J.H. is the recipient of NRSA Fellowship CA08805. R.J.S. is the recipient of Deutsche Forschungsgemeinschaft Fellowship Sche 309/1-2.

Correspondence should be addressed to Dr. John A. Wagner, Department of Neurology and Neuroscience, Cornell University Medical College, 1300 York Avenue, Room E615, New York, NY 10021.

Copyright (C) 1992 Society for Neuroscience $0270-6474 / 92 / 122573-09 \$ 05.00 / 0$
Kaplan et al., 1991; Klein et al., 1991; Meakin and Shooter, 1991). Many studies have examined the molecular mechanism of NGF action, and a number of second messenger pathways and protein modifications have been shown to be under the control of NGF (for a recent review, see Halegoua et al., 1991). Nevertheless, the essential signal transduction pathways leading to the expression of the neural phenotype have not yet been unambiguously established.

PC1 2 is a clonal rat line that is a useful model system to study NGF's mechanism of action. In response to NGF, PC12 cells differentiate into sympathetic neuron-like cells, as indicated by the expression of a number of morphological and biochemical markers of differentiation including the formation of processes, increases in neurotransmitter synthesis, and increased electrical excitability (for a review, see Greene and Tischler, 1982). NGF appears to act through a number of signal transduction systems in PC12 cells. For example, NGF stimulates tyrosine phosphorylation of several proteins in PC12 cells (Maher, 1989). NGF also activates several serine/threonine kinases including the MAP2/ERK kinases (Miyasaka et al., 1990; Tsao et al., 1990; Boulton et al., 1991), a proline-directed kinase (Vulliet et al., 1989), the N-kinase (Volonte et al., 1989), S6 kinases (Blenis and Erikson, 1986), and protein kinase $C$ (Cremins et al., 1986; Hama et al., 1986; Heasley and Johnson, 1989). Analogs of cAMP mimic a number of the effects of NGF, and the cAMP-dependent protein kinases (PKA) have been implicated in mediating NGF activation of tyrosine hydroxylase (Cremins et al., 1986), induction of the voltage-dependent sodium channel (Kalman et al., 1990), and the downregulation of calmodulindependent kinase activity (Brady et al., 1990). Nevertheless, PC12-derived cells deficient in PKA are still capable of responding to NGF both biochemically and morphologically (Van Buskirk et al., 1985; Ginty et al., 1991), suggesting that PKA does not have an essential role in most of the actions of NGF.

Although some transcription-independent mechanisms are essential for NGF-induced differentiation of PC12 cells, there are also changes in gene expression that are necessary for NGF to elicit differentiation and subsequent neurite outgrowth in PC1 2 cells (Burstein and Greene, 1978; Greene et al., 1982). Several genes are transcriptionally activated in PC12 cells by NGF. For example, NGFI-A/d2 (Changelian et al., 1989; Cho et al., 1989), c-fos, c-myc, and $\beta$-actin (Greenberg et al., 1985; Kruijer ct al., 1985), ornithine decarboxylase (Hatanaka ct al., 1978; Feinstein et al., 1985), and c-jun (Wu et al., 1988) are rapidly and transiently induced by NGF independent of new protein synthesis. The induction of these immediate-early genes may be required for subsequent changes in gene expression. In addition, NGF increases the expression of several genes at later 
times by both transcriptional and posttranscriptional mechanisms, including several neurofilament subunits (Lindenbaum et al., 1988; Ikenaka et al., 1990), GAP-43 (Karns et al., 1987; Federoff et al., 1988), SCG10 (Anderson and Axel, 1985; Stein et al., 1988), a voltage-dependent sodium channel (Mandel et al., 1988), peripherin (Leonard et al., 1988), transin (Machida et al., 1989), two putative calcium-binding proteins (Masiakowski and Shooter, 1988), neurotensin/neuromedin (Kislauskis and Dobner, 1990), and the external glycoprotein NILE (McGuire et al., 1978; Salton et al., 1983).

Several independent cDNA clones have been isolated during screens for genes that are rapidly induced by NGF in PC1 2 cells (Leonard et al., 1987; Cho et al., 1989), one of which we named a2. The sequence of the a 2 cDNA was nearly identical to that of the gene NGF33.1 (Salton et al., 1991), which appears to be an independent isolate of the VGF cDNA (Levi et al., 1985; Salton et al., 1991). We will refer to the a 2 gene as VGF. The VGF polypeptide is stored in secretory vesicles and released through a regulated pathway in PC12 cells (Possenti et al., 1989). Immunocytochemical localization of VGF protein has demonstrated a specificity for brain tissue, with strong expression in the suprachiasmatic nucleus (van den Pol et al., 1989). This specificity is also reflected at the RNA level, with detectable quantities of VGF found only in the brain and spinal column (Salton et al., 1991). Finally, NGF has been shown to maximally induce VGF transcription (Cho et al., 1989) and accumulation of RNA (Salton et al., 1991; R. J. Hawley, unpublished observations) in PC1 2 cells, although some induction by other agents also occurs.

To gain a better understanding of how NGF acts to induce gene activity transcriptionally, we have used transfection of chloramphenicol acetyl transferase (CAT) reporter constructs into $\mathrm{PC} 12$ cells to assess promoter requirements for NGF induction of the VGF gene. These studies demonstrated that a consensus cAMP-dependent response element (CRE) appears to be essential for induction of the expression of the VGF gene by both NGF and cAMP.

\section{Materials and Methods}

$c D N A$ sequence analysis. The VGF $\mathrm{cDNA}$ a2-3 was selected from a $\lambda \mathrm{gt}-$ $10 \mathrm{cDNA}$ library of PC1 2 cells treated for $2 \mathrm{hr}$ with NGF using a partial clone from the same library (Cho et al., 1989) and subcloned by partial EcoRI digestion into the EcoRI site of pBluescript SK + (Stratagene). Nested deletions from polylinker sequences at the $5^{\prime}$ and $3^{\prime}$ end of the a2-3 insert were made by the ExolII/S1 method (Henikoff, 1984) using a commercially available kit (Erase-A-Base, Promega Biotec). Singlestranded DNA, produced by helper phage infection of cultures carrying the Bluescript phagemids, was sequenced using the Sequenase dideoxy kit (U.S. Biochemicals). In some cases, oligonucleotide primers were synthesized for use as ahove. Approximately $80 \%$ of the a $2-3$ clone was sequenced in both directions. In some GC-rich regions in which unambiguous sequence could not be obtained as above, a Taq polymerase protocol (I.B.I.) was used. The deduced amino acid sequence from a2-3 was searched against GenBank, release 67 (and earlier versions), with the Autosearch program at the National Center for Biotechnology Information, using the Blast network service. The sequences of the a 2 cDNA and the $5^{\prime}$ genomic DNA (see below) have been submitted to GenBank under assession numbers M74223 and M74224, respectively.

Genomic clone isolation and mapping. A rat genomic library (Tamkun et al., 1984) was screened for VGF genomic sequences using the entire a 2-3 cDNA clone as probe. A 9.8 kilobase (kb) EcoRI fragment, which hybridized to a2-3 sequences upstream of the EcoRI site in a2-3, was isolated from a genomic clone and subcloned into pBluescript $\mathrm{SK}+$ to create $\mathrm{a} 2 \mathrm{G}-1$, which was subsequently used for construction of promoter reporter plasmids. A 700 base pair bp SacI/KpnI fragment, contained within in the $9.8 \mathrm{~kb}$ EcoRI fragment, hybridized to an oligonucleotide,
5'-TCGAGGGCTGGCGTCCT-3', complementary to nucleotides near the $5^{\prime}$ end of the a2-3 cDNA. This fragment was also subcloned into the SK + vector, and genomic sequence was obtained from the upstream (SacI) end using a vector-complementary primer, and on the opposite strand using the a2-3 oligonucleotide primer, as described for cDNA clone sequencing. Primer extension analysis (Hawley and Waring, 1988) using this same oligonucleotide primer and RNA isolated from untreated and 2 hr NGF-treated PC12 cells was used to determine the transcription initiation site.

$V G F$ reporter constructs. Sequence downstream of the transcription start site in genomic subclone a2G-1 (see above) was shortened by ExoIII/S1 deletion from polylinker sequences flanking the distal end of the fragment. A deletion subclone ( $2 \mathrm{G} \Delta \mathrm{\Delta}$ b) containing 23 nucleotides (nt) of $5^{\prime}$ untranslated sequence was chosen for all reporter constructs. Fragments of this subclone were cleaved from the vector at the $3^{\prime}$ end of the insert by digestion at a polylinker-derived $\mathrm{KpnI}$ site and at various points upstream of the transcription start with the following enzymes: SacI, -210; HindIII, - 700; PstI, - 1200; SpeI, -3100; BamHI, -5900 (except for SacI, fragment ends are estimates from restriction digests). The ends of these fragments were blunted with Klenow fragment and ligated to BamHI linkers for insertion into the BamHI sites of pBLCAT3 (Luckow and Schutz, 1987) or $\mathrm{p} \phi \mathrm{GH}$ (Selden et al., 1986).

To construct CRE mutant $-210 /+23 \Delta C R E$, plasmid a2G $\Delta 5$ b was digested at a unique AatII site within the CRE. Treatment with Klenow blunted the ends, removing $4 \mathrm{nt}$. After religation, the SacI/KpnI fragment was isolated for cloning into pBLCAT3 as described above. Plasmid-207/ +23 was constructed using an NheI/BamHI $\left(5^{\prime}\right.$ end $-207 ; 3^{\prime}$ end BamHI linker) fragment from $-210 /+23$. This fragment was ligated into an $\mathrm{XbaI} / \mathrm{BamHI}$-cleaved $\mathrm{pBLCAT} 3$ derivitive in which a unique AatII site had been eliminated (Sheng et al., 1990); the ligation created a hybrid site not recognized by NheI. To construct $-207 /+23$ mutCRE, the above plasmid was digested within the CRE at the AatII site, blunted with Klenow, and ligated to complementary oligomers (5'CTAGCACACTAGTTAGCTAG-3' and complement), which created NheI sites at each end of the insertion. The resultant plasmid was then cleaved with NheI and religated to obtain a plasmid in which the wild-type CRE sequence, TGACGTCA, was changed to TGCTAGCA. All constructs were verified by DNA sequencing.

PCI2 cell transfection. For generation of stable transfectant lines, PC1 2 cells were plated the night before transfection at a density of $5 \times$ $10^{\circ}$ cells $/ 75 \mathrm{~cm}^{2}$ flask in Dulbecco's modified Eagle's medium (DMEM) supplemented with 10\% fetal bovine serum (Flow Laboratories) and 5\% horse serum (K.C. Biologicals). The following day, cells were washed three times with serum-free media prior to addition of $6 \mathrm{ml}$ of lipofection transfection media (Felgner et al., 1987). Transfection media contained $5 \mu \mathrm{g} / \mathrm{ml}$ VGF-reporter construct, $0.5 \mu \mathrm{g} / \mathrm{ml}$ pRSVneo (Gorman et al., 1983 ), and $8 \mu \mathrm{g} / \mathrm{ml}$ Lipofectin in serum-free DMEM (pH 8.2). After 5 hr incubation, transfection media was replaced with normal serumcontaining media. Seventy-two hours following transfection, cells were selected with media containing $400 \mu \mathrm{g} / \mathrm{ml} \mathrm{G} 418$; cells were re-fed G418 containing media every $3 \mathrm{~d}$. After $10-14 \mathrm{~d}$, colonies (100-300/flask) were counted, harvested, and replated to produce a polyclonal culture. After reaching confluence, portions of the polyclonal cultures were frozen and the remainder was passaged as for PC12 cells in medium containing G418. G418 was removed from the culture media at least 1 week before plating for reporter assays. For transient assays, cells were transfected as above (at $10^{7}$ cells/flask but without pRSVneo) and split the following day into $60 \mathrm{~mm}$ dishes at a density of $10^{6} \mathrm{cells} /$ dish.

Reporter assays. Stably transfected PC1 2 lines were plated at a density of $10^{6}$ cells $/ 60 \mathrm{~mm}$ dish the day before treatment. Cells were treated, without media change, for $16 \mathrm{hr}$ with the following agents: $100 \mathrm{ng} / \mathrm{ml}$ NGF, $100 \mathrm{ng} / \mathrm{ml}$ acidic fibroblast growth factor (aFGF), $10 \mathrm{ng} / \mathrm{ml}$ basic FGF (bFGF), $10 \mathrm{ng} / \mathrm{ml}$ epidermal growth factor (EGF), $10 \mu \mathrm{M}$ forskolin, $1 \mathrm{mM}$ dibutyryl cAMP (db-cAMP), and $100 \mathrm{nM}$ phorbol 12-myristate 13-acetate (PMA). Following treatment, lysates were prepared by three freeze-thaw cycles in $250 \mathrm{~mm}$ Tris- $\mathrm{HCl}$. Chloramphenicol acetyl transferase (CAT) activity was assayed using butyryl coenzyme $A$ as acyl donor and extraction of butyrylated chloramphenicol with TMPD/xylenes as previously described (Seed and Sheen, 1988). All treatments were performed in duplicate; assays of duplicate plates generally differed by less than $20 \%$. CAT assays of transiently transfected cells were performed as above, with $16 \mathrm{hr}$ treatments commencing $48 \mathrm{hr}$ following transfection. Growth hormone assays of culture media from transiently transfected cells were performed $16-24 \mathrm{hr}$ following treatment using a commercial assay kit (Nichols Institute Diagnostics).

DNA mobility shift assays. Probes for mobility shift experiments were 
prepared by Klenow labeling of BanI/BssHII fragments (promoter region -111 through -41 ) of the VGF-CAT constructs $-207 /+23$ and $-207 /+23$ mutCRE. Annealed oligonucleotides containing the CRE and adjacent sequence (5'-CTCCTTGGCTGACGTCAGAGAGAGG-3') from the somatostatin gene (Montminy et al., 1986) or an unrelated 20mer (5'-CTAGCACACTAGTTAGCTAG-3') were used as competitors. a244 CREB antiserum (a gift of Marc Montminy, University of California, San Diego; Yamamoto et al., 1990) and preimmune rabbit serum were used at a final dilution of 1:50.

Binding assays were performed in $10 \mu 1$ reactions containing $10 \mathrm{~mm}$ HEPES (pH 7.9), $1 \mathrm{mM} \mathrm{MgCl}_{2}, 50 \mathrm{~mm} \mathrm{KCl,} 1 \mathrm{~mm}$ dithiothreitol, $0.05 \%$ $\mathrm{NP}-40,50 \mu \mathrm{g} / \mathrm{ml}$ sheared salmon testis DNA, $50 \mu \mathrm{g} / \mathrm{ml}$ poly $(\mathrm{dI}-\mathrm{dC})$, $500 \mu \mathrm{g} / \mathrm{ml}$ BSA, $5 \%$ glycerol, and approximately $1 \mu \mathrm{g} / \mathrm{ml}$ baculovirusexpressed CREB (Gonzalez et al., 1989) protein (a gift of Cindy Miranti and Mike Greenberg, Harvard Medical School). All components except probe, including competitors or sera, were assembled and incubated 10 $\mathrm{min}$ at room temperature. Reactions were incubated an additional 30 min at room temperature following addition of $50 \mathrm{pg}\left(2 \times 10^{4} \mathrm{cpm}\right)$ of probe DNA. Reactions were electrophoresed at $4^{\circ} \mathrm{C}$ on prerun $4 \%$ polyacrylamide gels $(1.25 \%$ cross-linked) in $0.5 \times \mathrm{TBE}$ ( $50 \mathrm{~mm}$ Tris, $50 \mathrm{mM}$ boric acid, 1 mM EDTA, pH 8.3).

Northern blot analysis. For isolation of RNA, PC12 cells were plated at a density of $4 \times 10^{6} / 100 \mathrm{~mm}$ dish the day prior to treatment. Following treatment, cytoplasmic RNA was isolated by NP-40 lysis/proteinase $\mathrm{K}$ digestion and electrophoresed on a $1 \%$ agarose-formaldehyde gel (Maniatis et al., 1982) for transfer to nylon membranes (Nytran, Schleicher and Schuell). Blots were hybridized for $12 \mathrm{hr}$ at $T_{m}-5^{\circ} \mathrm{C}$ $\left(62^{\circ} \mathrm{C}\right)$ in $6 \times$ SSPE, $0.5 \%$ SDS, $50 \mu \mathrm{g} / \mathrm{ml}$ polyA acid, $50 \mu \mathrm{g} / \mathrm{ml}$ heparin with $10^{7} \mathrm{cpm} / \mathrm{ml}$ of oligonucleotide probe labeled with T4 polynucleotide kinase and $\gamma{ }^{32} \mathrm{P}$-ATP $(6000 \mathrm{Ci} / \mathrm{mmol})$. Following hybridization, blots were rinsed three times for 5 min each in $6 \times$ SSPE, $1 \%$ SDS and then washed once for $2 \mathrm{~min}$ in the same solution at $62^{\circ} \mathrm{C}$. Oligonucleotides used were 5'-GAGAACGCTCGCAATCCTCGT-3' for the exon 2-specific probe and 5'-CTGCCAGAGACAGCCGGTGT-3' for the exon 1/exon 3 junction probe.

Materials. Lipofectin was obtained from Bethesda Research Laboratories (Gaithersburg, MD). $\beta$-NGF was prepared in this laboratory as described by Mobley et al. (1976). EGF, db-cAMP (N6, 2'-0-dibutyryladenosine $3^{\prime}: 5^{\prime}$ cyclic monophosphate), and PMA were obtained from Sigma Chemical Co. aFGF was purchased from Promega Biotec. bFGF was kindly provided by P. D'Amore (Harvard Medical School).

\section{Results}

$V G F$ gene transcripts. We determined the nucleic acid sequence of the a2-3 cDNA by dideoxy sequencing as described in Materials and Methods. In a homology search of the PIR protein database, extensive regions of perfect match were found between the deduced amino acid sequences of a2-3 and the VGF8 a cDNA (Possenti et al., 1989). Most discrepancies hetween the two deduced sequences could be explained by frame shifts within several GC-rich regions of the gene, and a shift in the VGF8a sequence that extends the open reading frame into the $3^{\prime}$ untranslated portion of the a2-3 sequence. Recently, the sequence of another VGF cDNA clone (NGF33.1) has been published by Salton et al. (1991). The deduced amino acid sequence of the a2-3 cDNA agrees completely with that of the NGF33.1 clone, and it will not be repeated here. Based upon our sequence comparisons and Southern analysis of rat genomic DNA by Salton et al. (1991), we believe the a2-3, NGF33.1, and VGF8a clones all represent transcripts from a single VGF gene.

Comparison of the nucleotide sequences of the NGF33.1 and a2-3 cDNA clones revealed a major difference within the $5^{\prime}$ untranslated regions of the two clones. A 116 bp sequence, present in NGF33.1, is not found in the a2-3 clone (Fig. 1A). Comparison of cDNA and genomic sequences of the VGF gene (Salton et al., 1991) demonstrates that this sequence corresponds exactly to exon 2 of the VGF gene. Thus, the a2-3 cDNA likely represents an alternatively spliced message, composed solely of exons 1 and 3 of the VGF gene.
To confirm the existence of alternatively spliced VGF messages, and to determine if alternative forms may be differentially regulated by NGF, we hybridized duplicate Northern blots of PC12 RNA from untreated cells and from cells treated with NGF or db-cAMP to oligonucleotide probes complementary to cither sequence within exon 2 or to the sequence spanning the junction of exons 1 and 3 (Fig. $1 B$ ). As the junction-spanning probe contains only $10 \mathrm{nt}$ on either side of exon 2 , it will not hybridize to transcripts containing exon 2 under the hybridization conditions used in the experiment. Both specific oligonucleotide probes detected a $\mathrm{PC} 12$ cell transcript of approximately $2.7 \mathrm{~kb}$, which is induced by both NGF and db-cAMP. The qualitalively similar profiles seen with the two probes suggest that no obvious regulatory differences exist between these messages in PC12 cells under the conditions examined. As previously noted (Cho et al., 1989; Hawley, unpublished observations), induction of VGF RNA accumulation by NGF is greater than that seen with db-cAMP, although both agents induce transcriptional activity to a similar degree. These data suggest that NGF and db-cAMP may have different posttranscriptional effects on VGF accumulation.

$A$ limited upstream region is required for induction of the $V G F$ gene by NGF. Nuclear runoff assays have demonstrated that the VGF gene is transcriptionally induced in $\mathrm{PC} 12$ cells approximately fivefold within $2 \mathrm{hr}$ of treatment by NGF and db-cAMP, and to a lesser extent by PMA, aFGF, and EGF (Cho et al., 1989; Hawley, unpublished observations). To determine the extent of upstream sequences required for induction by NGF, we constructed reporter plasmids containing various amounts of upstream sequence and the first $23 \mathrm{bp}$ of $5^{\prime}$ untranslated sequence. Preliminary experiments, in which CAT and $\mathrm{hGH}$ reporter constructs containing from 210 to 5900 bp of upstream sequence were assayed by transient transfection in PC12 cells, indicated that CAT activities could be induced up to threefold with each of these constructs by treatment with NGF.

To confirm and extend these findings, we created stably transfected polyclonal lines by cotransfection of PC12 cells with a VGF-CAT reporter construct and pRSVneo, followed by selection for G418 resistance. Lines obtained by transfection with constructs containing 23 bp of $5^{\prime}$ untranslated VGF sequence and either 210 or $1200 \mathrm{bp}$ of upstream sequence were treated with various agents for $16 \mathrm{hr}$. CAT activity in both of these lines was consistently increased approximately threefold following treatment with either NGF or the cAMP kinase activators db-cAMP and forskolin (Fig. 2). In contrast, the CAT expression in these lines was only minimally induced by aFGF, bFGF, EGF, and PMA. Neither basal nor induced CAT activity was detectable in a similarly transfected polyclonal line containing only the pBLCAT3 vector (not shown).

The level of CAT activity induced by NGF and by cAMP kinase activators reasonably approximates the inductions seen in nuclear runoff experiments with the endogenous VGF gene. Thus, most or all sequences necessary for mediating the transcriptional response to these agents are found with the first 210 nt upstream of the transcription start site. The lower inductions sccn with aFGF, bFGF, PMA, and EGF may reflect the lower level of transcriptional induction seen in nuclear runoff experiments with these agents. Alternatively, lower reporter levels may result from a more transient transcriptional induction by these agents or the absence of regulatory sequences in our constructs required for induction by these agents.

$A C R E$ element in the VGF promoter is required for $N G F$ 




GAGCGAGAGCGCTGTTGCTGACCCAGCTGAGCCCAGCTCCTAGGACGC CAGCGTGCTGAAGCCGGAGCGAGAGCGCTGTTGCTGACCCAGCTGAGCCCAGCTCCTAGGACGC CAGCCCTCGACCATCTTTCATACTCCAGCCACGGAACGGAGCCAGGGCAGACGGGTCCGGATTT CAGCCCTCGACCATCTTTCATACTCCAGCCACGGAACGGAGCCAGGGCAGACGGGTCCGGATTT

TCCCCCTGCCCCGACCCTCCTCTCCACCTCCCGCCGTCGTGACACCGGCTC

EXON 1

GGGGC

B

\section{EXON 2 EXON 3}

Figure 1. Alternative splicing of VGF transcripts. $A$, Nucleotide sequences of $5^{\prime}$ untranslated regions of the a2-3 and NGF33.1 cDNA clones. a2-3 sequence NGF33.1 sequence is shown through the cap site indicated by Salton et al. (1991). The two sequences differ only by a deletion of exon 2 in a2-3. Nucleotides complementary to the specific oligonucleotide probes for exon 2 and the exon 1/exon 3 junction (below) are underlined. $B$, Northern blot analysis of alternatively spliced VGF transcripts. Cytoplasmic RNA was prepared from $\mathrm{PC} 12$ cells treated as indicated and electrophoresed in duplicate on the same gel. Top, Hybridization to the exon 1/exon 3 junction-specific oligonucleotide probe 5'-CTGCCAGAGACAGCCGGTGT-3'. Bottom, Hybridization to the exon 2-specific oligonucleotide probe 5'-GAGAACGCTCGCAATCCTCGT-3'. Equivalent exposures for the two probes are shown. $d b c$, db-cAMP. begins at the actual 5 ' end of the cDNA;

responsiveness. The sequence of the first 210 bp upstream of the VGF gene that contains cis-acting regulatory elements necessary for induction gene by NGF and cAMP kinase activators is shown in Figure 3. Consensus TATA and CCAAT elements are found at -33 and -141 , respectively. Three additional sequence elements previously shown to mediate transcriptional activity are also found within this region. Two GC boxes, potential binding sites for transcription factor SP1 (Kadonaga et al., 1987), are located at -71 and -108 . A region at -82 to -75 is identical to the consensus $8 \mathrm{bp}$ palindromic sequence of the core of the CRE found in many cAMP-regulated genes (Montminy et al., $1986,1990)$. The CRE core consensus is embedded within a 14 bp palindrome also found in a repeated element in the cAMPinducible promoter for the major immediate-early gene of human cytomegalovirus (Hunninghake et al., 1989). No consensus serum-response element (SRE) or AP-1 site, elements previously associated with NGF transcriptional induction (Visvader et al., 1988; Gizang-Ginsberg and Ziff, 1990), was found within the first 210 bp upstream of the VGF gene.

Since the only element previously shown to function in transcriptional induction within the -210 region was the CRE at -82 , we examined the effect mutagenizing this element would have on the NGF- and CAMP-mediated induction of CAT reporter activities. Polyclonal lines were established as described above with the construct $-210 /+23 \Delta \mathrm{CRE}$, which differed from the $-210 /+23$ construct by deletion of the central $4 \mathrm{nt}$ from the 8 bp CRE core sequence. As shown in Figure $4 A$, deletion of the four bases nearly eliminated induction of CAT activity by NGF, db-cAMP, and forskolin. To confirm the importance of the CRE element in mediating NGF and cAMP inductions of the VGF reporter constructs, we established polyclonal lines with two additional constructs. The vector used for these constructs differed from the pBLCAT3 vector previously used by the elimination of a potential CRE within pBLCAT3 sequences upstream of the VGF cloning site (Sheng et al., 1990). A polyclonal line transfected with a CAT reporter construct containing nucleotides -207 to +23 of the VGF gene was induced by NGF, db-cAMP, and forskolin to a degree quantitatively similar to that transfected with the $-210 /+23$ construct (Fig. $4 A, B$ ). A second construct, $-207 /+23$ mutCRE, differed from this construct only by substitution of four bases within the CRE core. This substitution, changing the CRE core sequence from TGACGTCA to TGCTAGCA, preserved both the spacing of sequences to either side of the CRE and the extended palindromic nature of the region. As was the case for the CRE deletion mutant, induction of CAT activity was greatly reduced in a polyclonal line transfected with this construct (Fig. 4B). Together, these results demonstrate that the inductions of CAT activity by NGF and cAMP kinase activators are critically dependent on the CRE element. Furthermore, because basal CAT 




Figure 2. Induction of VGF-CAT constructs in $\mathrm{PC1} 2$ polyclonal stable lines. Constructs containing either $210 \mathrm{bp}$ or approximately $1200 \mathrm{bp}$ of VGF genomic upstream sequence and $23 \mathrm{bp}$ of $5^{\prime}$ untranslated region were cloned into pBLCAT 3 and transfected into PC1 2 cells as described. Stable polyclonal lines, selected by cotransfection of pRSVneo, were plated and treated with the agents shown for $16 \mathrm{hr}$ as described in Materials and Methods. Cell lysates were assayed by extraction of butyrylated ${ }^{14} \mathrm{C}$-chloramphenicol as described (Seed and Sheen, 1988). Induction folds are the ratio of counts in lysates of treated cells to counts in lysates of untreated cells, after subtraction of assay background $(<10 \%$ of basal counts). Values are the average of three trials, each performed in duplicate. Error bars represent SE.

activities in these two lines were indistinguishable, loss of induction in the mutant construct is not a trivial consequence of the loss of an element required for basal transcription. We conclude that the sequence between -82 and -75 functions as a $\mathrm{CRE}$ and is required for the induction of VGF by db-cAMP. Since this element also mediates the induction of VGF by NGF, it may also be considered an essential component of an NGF response element.

A VGF promoter fragment containing the wild-type, but not mutant, CRE binds transcription factor CREB. A CRE binding transcription factor, CREB, has previously been identified in nuclear extracts of PC12 cells (Montminy and Bilezikjian, 1987) and shown to mediate transcription induction by cAMP (Montminy and Bilezikjian, 1987; Yamamoto et al., 1988). Since the CRE consensus site within the VGF promoter is required for induction of VGF-CAT constructs by NGF and cAMP, we examined the ability of our wild-type and mutant VGF promoters to bind CREB. Labeled restriction fragments containing the region from -111 through -41 (Fig. 3) were prepared from the wild-type VGF-CAT construct $-207 /+23$ and from the mutant construct $-207 /+23$ mutCRE and analyzed by gel mobility shift using purified baculovirus-expressed CREB. Purified CREB specifically binds the wild-type but not mutant probe (Fig. 5, lanes $1,2)$. Furthermore, binding to the wild-type probe is compeated by a double-stranded oligomer containing the CRE core and adjacent sequence from the somatostatin gene, but not by an unrelated oligomer (Fig. 5, lanes 3, 4). Finally, all retarded complexes containing the wild-type probe are further retarded by incubation in the presence of a CREB antiserum (Fig. 5, lane 5 ), ruling out the possibility that a contaminating protein is the probe binding factor. We conclude that the wild-type CRE in the VGF gene is capable of binding the inducible transcription factor CREB, and that the same $4 \mathrm{bp}$ mutation that nearly eliminates NGF and cAMP induction of our VGF-CAT constructs also eliminates CREB binding potential.

\section{Discussion}

Using PC12 pheochromocytoma cells as a model system for NGF action, NGF-dependent neuronal differentiation has been shown to involve both transcriptional and nontranscriptional mechanisms (Burstein and Greene, 1978). In order to gain a better understanding of how NGF acts to induce gene activity transcriptionally, we have used transfection of CAT reporter constructs into PC12 cells to assess promoter requirements for NGF induction of the VGF gene. Although the function of the VGF protein remains unknown, specific localization of VGF expression to neural tissue and the maximal induction of VGF transcription and RNA accumulation by NGF make the gene an interesting candidate for this analysis.

Analysis of NGF induction of VGF-CAT reporter constructs in PC12 transient and stable assays demonstrated that at most 207 bp of VGF upstream sequence are required for full induction. Sequence analysis of this region revealed a relatively simple promoter structure, containing CCAAT and TATAA consensus sites, two potential binding sites for the noninducible transcriptional activator SP1, and a consensus CRE sequence within a $14 \mathrm{bp}$ palindrome. Mutagenesis of the CRE, by deletion or by a substitution that maintained the 14 bp palindrome, nearly abolished NGF inducibility. In contrast, mutation of the CRE had no effect on basal promoter activity. The CRE in the VGF promoter thus appears to be essential for mediating transcriptional induction by NGF, but not transcriptional competence.

Promoter elements required for induction by NGF have been analyzed for the c-fos, tyrosine hydroxylase, and neurotensin genes. NGF induction of c-fos (Visvader et al., 1988) in trans-

CCGCTAGCTC ACGCCCCTCT AGCCGAGGGC -181

\section{CCAAT}

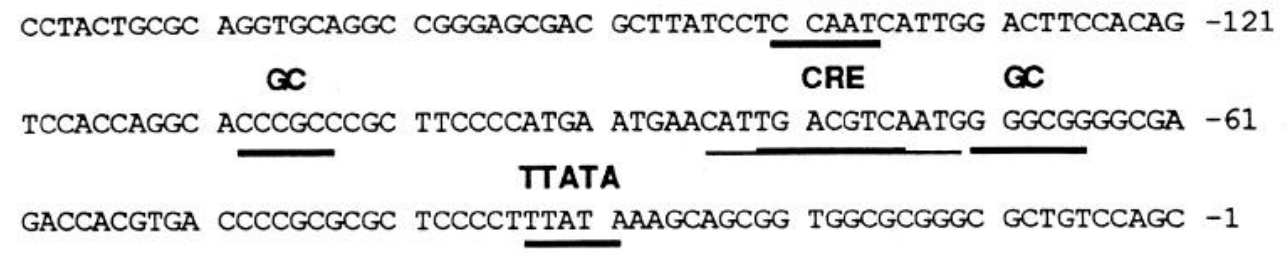

GTGCTGAAGC CGGAGCGAGA GCG +23
Figure 3. Sequence of the VGF genomic region in VGF-CAT constructs $-210 /+23$ and $-207 /+23$. Consensus CCAAT and TATAA elements are found at -141 and -33 , respectively. Two GC boxes, consensus binding sites for transcription factor SP1, are located at -98 and -71 . A consensus CRE at -82 is contained within a 14 bp palindrome. 


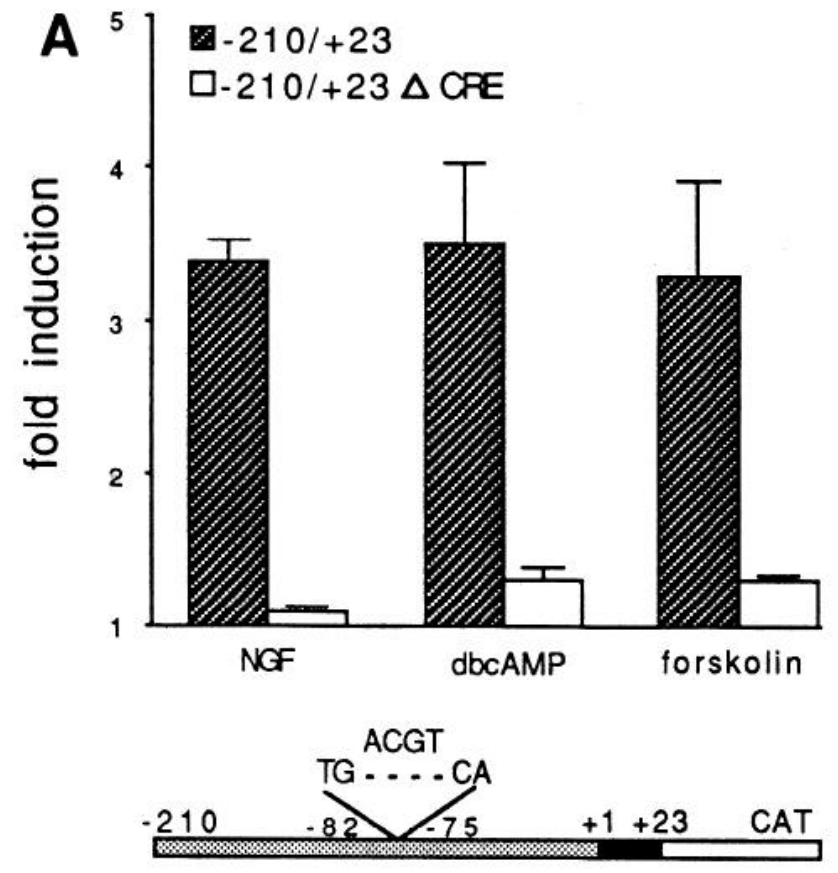

$-210 /+23 \triangle C R E$



\section{$-207 /+23$ mutCRE}

Figure 4. Analysis of VGF promoter mutations. $A$, Induction of CAT activity in $-210 /+23$ and $-210 /+23 \Delta C R E$ polyclonal lines. As indicated, the $-210 /+23 \Delta C R E$ construct contains a 4 bp deletion from the center of the CRE core. $B$, Induction of CAT activity in $-207 /+23$ and $-207 /+23$ mutCRE polyclonal lines. The $-207 /+23$ mutCRE construct contains a substitution of the same $4 \mathrm{bp}$ as above, and maintains both relative spacing and the palindromic nature of the region including the CRE. Induction values are averages of three trials in duplicate, performed as described in Figure 2. Basal chloramphenicol conversion activities for the $-207 /+23$ and $-207 /+23$ mutCRE lines were $48 \pm$ $3.7 \mathrm{pmol} / \mathrm{hr} / 10^{6}$ cells and $50 \pm 2.3 \mathrm{pmol} / \mathrm{hr} / 10^{6}$ cells, respectively $( \pm \mathrm{SE}$ $n=3$ ).

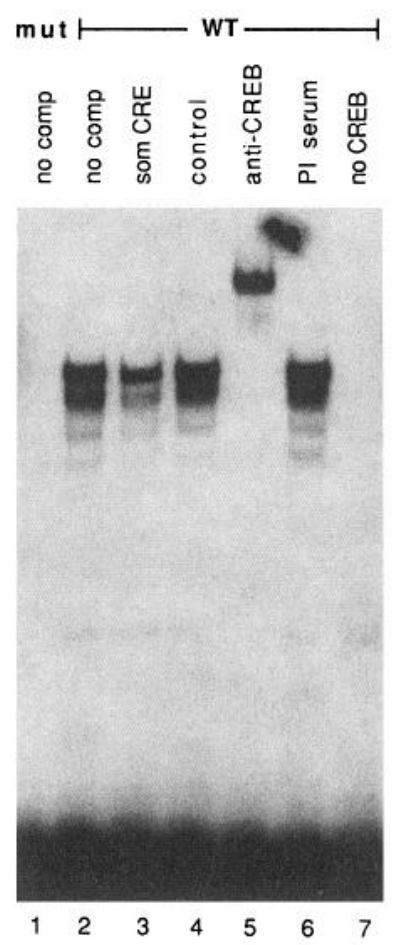

Figure 5. CREB binding to the CRE present in the VGF promoter. Probes containing the VGF promoter region from -111 through -41 were isolated from VGF-CAT constructs $-207 /+23$ (WT) and $-207 /$ +23 mutCRE ( $m u t$ ) and assayed for binding to baculovirus-expressed CREB protein by gel mobility shifts as described in Materials and Methods. Lane 1, CREB binding to mut probe. Lanes 2-7, CREB binding to $W T$ probe: lane 3 , competition by a 100 -fold molar excess of an annealed oligonucleotide containing the CRE and adjacent sequence from the somatostatin gene; lane 4 , competition with an unrelated (control) annealed oligonucleotide; lane 5, CREB binding in the presence of a 1:50 dilution of $\alpha 244$ anti-CREB antiserum (Yamamoto et al., 1990); lane 6, CREB binding in the presence of a 1:50 dilution of preimmune rabbit serum; lane 7 , no added CREB. CREB protein was present at an approximate concentration of $1 \mu \mathrm{g} / \mathrm{ml}$ in lanes $1-6$. Additional experiments (not shown) revealed increased competition between WT probe and the somatostatin CRE oligonucleotide at lower CREB concentrations.

fected PC12 cells is dependent upon two SRE elements located at positions -227 and -323 . A CRE-like sequence at -60 , later shown to mediate calcium and membrane depolarization induction of c-fos through the transcription factor CREB (Sheng et al., 1990), did not confer NGF inducibility in the absence of the SRE elements. Both NGF inducibility and basal promoter activity of the tyrosine hydroxylase gene (Gizang-Ginsberg and Ziff, 1990) are dependent on an element (TH-FSE) that contains a consensus AP-1 binding site. NGF was shown to increase binding of protein complexes, which include c-fos, to this element. Sequences mediating NGF induction of the neurotensin gene (Kislauskis and Dobner, 1990) are less well understood, as synergistically acting agents are required for induction. Transcriptional induction by NGF in combination with other agents is decreased by mutation of a consensus AP-1 site or both of two CRE-like (CGTCA, TGACATCA) sites. Finally, constructs containing 532 bp of upstream sequence from the NGFI-A gene (Changelian et al., 1989) transfected into PC12 cells have been shown to be NGF inducible. Potential transcription factor binding sites in this region include four SREs and a CRE at -140 , but the involvement of these elements in NGF induction has 
not been demonstrated. In none of these genes has a CRE, in the absence of other known sites for inducible transcription factors, been shown to mediate transcriptional induction by NGF. Thus, it is reasonable to conclude that NGF must regulate gene expression by a variety of different mechanisms.

Induction of VGF transcription by both NGF and PKA activators, as seen in nuclear runoff assays, along with the requirement of a CRE consensus sequence for NGF- and PKAmediated induction of VGF-CAT constructs, suggests that the NGF transcriptional induction is mediated through the CREB/ activating transcription factor (ATF) family of CRE binding proteins (Hai et al., 1989; Montminy et al., 1990). Transcriptional activation has been linked to phosphorylation of CREB by PKA (Montminy and Bilezikjian, 1987; Gonzalez and Montminy, 1989). However, induction by both NGF and cAMP does not imply that NGF must act via PKA. In addition to mediating signals through cAMP-dependent protein kinase, CREB is thought to be activated by calcium/membrane depolarization, possibly through phosphorylation by calcium/calmodulin-dependent protein kinase (Sheng et al., 1990, 1991; Dash et al., 1991). Recently, TGF- $\beta 1$ has been shown to stimulate phosphorylation of CREB through a pathway independent of PKA (Kramer et al., 1991). It is quite possible that signals mediated through the NGF receptor tyrosine kinase may converge on CREB as well. Indeed, preliminary Northern blot analysis of RNA from the PKA-deficient PC1 2 cell lines A126-1B2 (Van Buskirk et al., 1985) and 123.7 (Ginty et al., 1991) shows that VGF transcripts accumulate normally in response to NGF (R. J. Scheibe and D. D. Ginty, unpublished observations), suggesting that NGF and cAMP may act through independent pathways with respect to VGF induction.

The relatively simple structure of the VGF gene region required for NGF induction is interesting in light of the tissue specificity of expression seen for VGF RNA and protein. Such specificity could be provided by a unique arrangement of promoter elements within the VGF upstream region or by action of a yet unidentified element within this region. Examination of VGF-CAT expression in heterologous cell types should indicate whether the sequences necessary for NGF inducibility arc also sufficient to account for specific expression. We must also consider the possibility that sequences outside of the $-207 /$ +23 region can act as transcriptional repressors in other cells types. Findings with the neuronal-specific gene SCG10 are of interest in this regard. Although the SCG10 promoter resembles that of a constitutively expressed "housekeeping" gene, sequences within $1.6 \mathrm{~kb}$ upstream of the promoter have been found that suppress SCG10 expression in non-neuronal cells (Mori et al., 1990; Wuenschell et al., 1990). Although the SCG10 gene is transcriptionally induced in PC12 cells by NGF, elements specifically associated with the NGF induction have not yet been identified.

Hybridization experiments with specific oligonucleotide probes have confirmed the existence of at least two alternatively spliced VGF transcripts in $\mathrm{PCl} 2$ cells. As the sequence of these two transcripts differ only upstream of the first ATG codon, the functional consequence of alternative forms is not yet clear. Our limited data with PC1 2 cell RNA revealed no obvious difference in regulation by NGF or db-cAMP. Whether differences in regulation occur on a cell type-specific basis remains to be determined. Additionally, our results do not rule out the existence of additional alternatively spliced forms. Although NGF and agents that act as PKA activators induce transcription of the endogenous VGF gene and our VGF reporter constructs to a quantitatively similar degree, a much larger accumulation of VGF message is seen following treatment with NGF. This may suggest a posttranscriptional effect attributable to NGF but not to cAMP. Large levels of transcriptional induction by NGF appear to be limited to the "immediate-early" class of genes, including the genes c-fos and NGFI-A, transcripts of which rapidly decay following transcription. At the other end of the spectrum are genes for the neural-specific GAP-43 (Federoff et al., 1988) and the $68 \mathrm{kDa}$ neurofilament (Ikenaka et al., 1990) proteins, for which increases in RNA accumulation can be demonstrated following NGF treatment, with little if any evidence for transcriptional induction. We suggest that the VGF gene may represent an intermediate form of NGF regulation, where a modest transcriptional induction (three- to fivefold) may bc coupled with posttranscriptional mechanisms to yield an increase in RNA accumulation of 20-80-fold.

\section{References}

Anderson DJ, Axel R (1985) Molecular probes for the development and plasticity of neural crest derivates. Cell 42:649-662.

Blenis J, Erikson RL (1986) Regulation of protein kinase activities in PC12 pheochromocytoma cells. EMBO J 5:3441-3447.

Bothwell M (1991) Tissue localization of nerve growth factor and nerve growth factor receptor. Curr Top Microbiol Immunol 165:5570.

Boulton TG, Nye SH, Robbins DJ, Ip NY, Radziejewska E, Morgenbesser SD, DePinho RA, Panayotatos N, Cobb MH, Yancopoulos GD (1991) ERKs: a family of protein-serine/threonine kinases that are activated and tyrosine-phosphorylated in response to insulin and NGF. Cell 65:663-675.

Brady MJ, Nairn AC, Wagner JA, Palfrey HC (1990) NGF-induced down-regulation of CaM-dependent protein kinase III in PC12 cells is mediated by cAMP-dependent protein kinase. $\mathrm{J}$ Neurochem 54 : 1034-1039.

Burstein DE, Greene LA (1978) Evidence for RNA synthesis-dependent and -independent pathways in stimulation of neurite outgrowth by nerve growth factor. Proc Natl Acad Sci USA 75:6059-6063.

Changelian PS, Feng P, King TC, Milbrandt J (1989) Structure of the NGFI-A gene and detection of upstream sequences responsible for its transcriptional induction by nerve growth factor. Proc Natl Acad Sci USA 86:377-381.

Chao MV (1991) The membrane receptor for nerve growth factor Curr Top Microbiol Immunol 165:39-53.

Cho KC, Scarnes WS, Minsk B, Palmieri S, Jackson-Grusby L, Wagner JA (1989) NGF regulates genc cxpression by several distinct mechanisms. Mol Cell Biol 9:135-143.

Cremins J, Wagner JA, Halegoua S (1986) Nerve growth factor action is mediated by cyclic AMP- and $\mathrm{Ca}^{+2} /$ phospholipid-dependent protein kinases. J Cell Biol 103:887-893.

Dash PK, Karl KA, Colicos MA, Prywes R, Kandel ER (1991) cAMP response element-binding protein is activated by $\mathrm{Ca}^{2+} /$ calmodulinas well as cAMP-dependent protein kinase. Proc Natl Acad Sci USA $88: 5061-5065$.

Federoff HJ, Grabczyk E, Fishman MC (1988) Dual regulation of GAP-43 gene expression by nerve growth factor and glucocorticoids. J Biol Chem 263:19290-19295.

Feinstein SC, Dana SL, McConlogue L, Shooter E, Coffino P (1985) Nerve growth factor rapidly induces ornithine decarboxylase mRNA in PC12 rat pheochromocytoma cells. Proc Natl Acad Sci USA 82: 5761-5765.

Felgner PL, Gadek TR, Holm M, Roman R, Chan HW, Wenz M, Northrop JP, Ringold GM, Danielsen M (1987) Lipofection: a highly efficient, lipid-mediated DNA-transfection procedure. Proc Natl Ácad Sci USA 84:7413-7417.

Ginty DD, Glowacka D, DeFranco C, Wagner JA (1991) Nerve growth factor-induced neuronal differentiation after dominant repression of both type I and type II cAMP-dependent protein kinase activity. J Biol Chem 266:15325-15333.

Gizang-Ginsberg E, Ziff EB (1990) Nerve growth factor regulates ty- 
rosine hydroxylase gene transcription through a nucleoprotein complex that contains c-fos. Genes Dev 4:477-491.

Gonzalez GA, Montminy MR (1989) Cyclic AMP stimulates somatostatin gene transcription by phosphorylation of CREB at serine 133. Cell 59:675-680.

Gonzalez GA, Yamamoto KK, Fischer WH, Karr D, Menzel P, Biggs W, Vale WW, Montminy MR (1989) A cluster of phosphorylation sites on the cyclic AMP-regulated nuclear factor CREB predicted by its sequence. Nature 337:749-752.

Gorman C, Padmanabhan R, Howard BH (1983) High efficiency DNA mediated transformation of primate cells. Science 221:551-553.

Greenberg ME, Greene LA, Ziff EB (1985) Nerve growth factor and epidermal growth factor induce rapid transient changes in proto-oncogene transcription in PC12 cells. J Biol Chem 260:14101-14110.

Greene LA, Tischler AS (1982) PC12 pheochromocytoma cultures in neurobiological research. Adv Cell Neurobiol 3:373-414.

Greene LA, Burstein DE, Black MM (1982) The role of transcriptiondependent priming in nerve growth factor promoted neurite outgrowth. Dev Biol 91:305-316.

Hai T, Liu F, Coukos WJ, Green MR (1989) Transcription factor ATF cDNA clones: an extensive family of leucine zipper proteins able to selectively form DNA-binding heterodimers. Genes Dev 3:2083-2090.

Halegoua S, Armstrong RC, Kremer NE (1991) Dissecting the mode of action of a neuronal growth factor. Curr Top Microbiol Immunol 165:119-170.

Hama T, Huang K-P, Guroff G (1986) Protein kinase C as a component of a nerve growth factor-sensitive phosphorylation system in PC12 cells. Proc Natl Acad Sci USA 83:2353-2357.

Hatanaka H, Otten U, Thoenen H (1978) Nerve growth factor-mediated selective induction of ornithine decarboxylase in rat pheochromocytoma: a cyclic AMP-dependent process. FEBS Letts 92:313315.

Hawley RJ, Waring GL (1988) Cloning and analysis of the dec-1 female-sterile locus, a gene required for proper assembly of the Drosophila eggshell. Genes Dev 2:341-349.

Heasley LE, Johnson GL (1989) Detection of nerve growth factor and epidermal growth factor-regulated protein kinases in PC1 2 cells with synthetic peptide substrates. Mol Pharmacol 35:331-338.

Henikoff S (1984) Unidirectional digestion with exonuclease III creates targeted breakpoints for DNA sequencing. Gene 28:351-359.

Hunninghake GW, Monick MM, Liu B, Stinski MF (1989) The promoter-regulatory region of the major immediate-early gene of human cytomegalovirus responds to T-lymphocyte stimulation and contains functional cyclic AMP-response elements. J Virol 63:3026-3033.

Ikenakja K, Nakahira K, Takayama C, Wada K, Hatanaka H, Mikoshiba K (1990) Nerve growth factor rapidly induces expression of the $68 \mathrm{kDa}$ neurofilament gene by posttranscriptional modification in PC12h-R cells. J Biol Chem 265:19782-19785.

Kadonaga JT, Carner KR, Masiarz FR, Tijan R (1987) Isolation of a cDNA encoding transcription factor SP1 and functional analysis of the DNA binding domain. Cell 51:1079-1090.

Kalman D, Wong B, Horvai AE, Clinc MJ, O'Laguc PH (1990) Nerve growth factor acts through cAMP-dependent protein kinase to increase the number of sodium channels in PC12 cells. Neuron 4:355366.

Kaplan DL, Martin-Zanca D, Parada L (1991) Tyrosine phosphorylation and tyrosine kinase activity of trk proto-oncogene product induced by NGF. Nature 350:158-160.

Karns LR, Ng S-H, Freeman JA, Fishman MC (1987) Cloning of complementary DNA for GAP-43, a neuronal growth-related protein. Science 236:597-600.

Kislauskis E, Dobner PR (1990) Mutually dependent response elements in the cis-regulatory region of the neurotensin/neuromedin $\mathrm{N}$ gene integrate environmental stimuli in PC12 cells. Neuron 4:783795.

Klein R, Jing S, Nanduri V, O'Rourke E, Barbacid M (1991) The trk proto-oncogene encodes a receptor for nerve growth factor. Cell 65: 189-197.

Kramer IM, Koorneef I, de Laat SW, van den Eijnden-van Raaij AJM (1991) TGF- $\beta 1$ induces phosphorylation of the cyclic AMP responsive element binding protein in ML-CCI64 cells. EMBO J 10:10831089.

Kruijer W, Schubert D, Verma IM (1985) Induction of the protooncogene fos by nerve growth factor. Proc Natl Acad Sci USA 82: $7330-7334$
Leonard DGB, Ziff EB, Greene LE (1987) Identification and characterization of mRNAs regulated by nerve growth factor in PC12 cells. Mol Cell Biol 7:3156-3167.

Leonard DGB, Gorham JD, Cole P, Greene LA, Ziff EB (1988) A nerve growth factor-regulated messenger RNA encodes a new intermediate filament protein. J Cell Biol 106:181-191.

Levi A, Eldridge JD, Paterson BM (1985) Molecular cloning of a gene sequence regulated by nerve growth factor. Science 229:393-395.

Levi-Montalcini R, Angeletti PU (1968) Nerve growth factor. Physiol Rev 48:535-584.

Lindenbaum MH, Carbonetto S, Grosveld F, Flavell D, Mushynski WE (1988) Transcriptional and post-transcriptional effects of nerve growth factor on expression of the three neurofilament subunits in PC-12 cells. J Biol Chem 263:5662-5667.

Luckow B, Schutz G (1987) CAT constructions with multiple restriction sites for the functional analysis of eukaryotic promoters and regulatory elements. Nucleic Acids Res 15:5490.

Machida CM, Rodland KD, Matrisian L, Magun BE, Ciment G (1989) NGF induction of the gene encoding the protease transin accompanies neuronal differentiation in PC12 cells. Neuron 2:1589-1596.

Maher PA (1989) Role of protein tyrosine phosphorylation in the NGF response. J Neurosci Res 24:29-37.

Mandel G, Cooperman SS, Maue RA, Goodman RH, Brehm P (1988) Selective induction of brain type II $\mathrm{Na}^{+}$channels by nerve growth factor. Proc Natl Acad Sci USA 85:924-928.

Maniatis T, Fritsch EF, Sambrook J (1982) Molecular cloning: a laboratory manual. Cold Spring Harbor, NY: Cold Spring Harbor Laboratory.

Martin-Zanca D, Barbacid M, Prada LF (1990) Expression of the $t r k$ proto-oncogene is restricted to the sensory cranial and spinal ganglia of neural crest origin in mouse development. Genes Dev 4:683-694.

Masiakowski P, Shooter EM (1988) Nerve growth factor induced the genes for two proteins related to a family of calcium-binding proteins in PC12 cells. Proc Natl Acad Sci USA 85:1277-1281.

McGuire JC, Greene LA, Furano AV (1978) NGF stimulates incorporation of fucose or glucosamine into an external glycoprotein in cultured rat PC12 pheochromocytoma cells. Cell 15:357-365.

Meakin SO, Shooter EM (1991) Molecular investigations on the highaffinity nerve growth factor receptor. Neuron 6:153-163.

Miyasaka T, Chao MV, Sherline P, Saltiel AR (1990) Nerve growth factor stimulates a protein kinase in PC-12 cells that phosphorylates microtubule-associated protein-2. J Biol Chem 265:4730-4735.

Mobley WC, Schenker A, Shooter EM (1976) Characterization and isolation of proteolytically modified nerve growth factor. Biochemistry 15:5543-5551.

Montminy MR, Bilezikjian LM (1987) Binding of a nuclear protein to the cyclic AMP response element of the somatostatin gene. Nature 328:175-178.

Montminy MR, Sevarino KA, Wagner JA, Mandel G, Goodman RH (1986) Identification of a cyclic-AMP responsive element within the rat somatostatin gene. Proc Natl Acad Sci USA 83:6682-6686.

Montminy MR, Gonzalez GA, Yamamoto KK (1990) Regulation of cAMP-inducible genes by CREB. Trends Neurosci 13:184-188.

Mori N, Stein R, Sigmund O, Anderson DJ (1990) A cell type-preferred silencer element that controls the neural-specific expression of the SCG10 gene. Neuron 4:583-594.

Possenti R, Eldridge JD, Paterson BM, Grasso A, Levi A (1989) A protein induced by NGF in PC1 2 cells is stored in secretory vesicles and released through the regulated pathway. EMBO J 8:2217-2223.

Salton SRJ, Richter LC, Greene LA, Shelanski ML (1983) Nerve growth factor-inducible large external (NILE) glycoprotein: studies of central and peripheral neuronal marker. J Neurosci 3:441-454.

Salton SRJ, Fischberg DJ, Dong K-W (1991) Structure of the gene encoding VGF, a nervous system-specific mRNA that is rapidly and selectively induced by nerve growth factor in PC12 cells. Mol Cell Biol 11:2335-2349.

Seed B, Sheen J-Y (1988) A simple phase-extraction assay for chloramphenicol acyltransferase activity. Gene 67:271-277.

Selden RF, Burke-Howie K, Rowe ME, Goodman HM, Moore DD (1986) Human growth hormone as a reporter gene in regulation studies employing transient gene expression. Mol Cell Biol 6:31733179.

Sheng M, McFadden G, Greenberg ME (1990) Membrane depolarization and calcium induce c-fos transcription via phosphorylation of transcription factor CREB. Neuron 4:571-582. 
Sheng M, Thompson MA, Greenberg ME (1991) CREB: a Ca ${ }^{2+}$-regulated transcription factor phosphorylated by calmodulin-dependent kinases. Science 252:1427-1430.

Springer JE (1988) Nerve growth factor receptors in the central nervous system. Exp Neurol 102:354-365.

Stein R, Orit S, Anderson DJ (1988) The induction of a neural-specific gene, SCG10, by nerve growth factor in PC12 cclls is transcriptional, protein synthesis dependent, and glucocorticoid inhibitable. Dev Biol 127:316-325.

Sutter A, Riopelle RJ, Harris-Warrick RM, Shooter EM (1979) Nerve growth factor receptors. Characterization of two distinct classes of binding sites on chick embryo sensory glial cells. J Biol Chem 254: 5972-5982.

Tamkun JW, Schwarzbauer JE, Hynes RO (1984) A single rat fibronectin gene generates three different mRNAs by alternative splicing of a complex exon. Proc Natl Acad Sci USA 81:5140-5144.

Thoenen H, Barde YA (1980) Physiology of nerve growth factor. Physiol Rev 60:1284-1334.

Tsao H, Aletta JM, Greene LA (1990) Nerve growth factor and fibroblast growth factor selectively activate a protein kinase that phosphorylates high molecular weight microtubule-associated proteins. J Biol Chem 265:15471-15480.

Van Buskirk R, Corcoran T, Wagner JA (1985) Clonal variants of PC12 pheochromocytoma cells with defects in cAMP-dependent protein kinases induce ornithine decarboxylase in response to NGF but not to adenosine agonists. Mol Cell Biol 5:1984-1992. van den Pol AN, Decavel C, Levi A, Paterson B (1989) Hypothalamic expression of a novel gene product, VGF: immunocytochemical analysis. J Neurosci 9:4122-4137.

Visvader J, Sassone-Corsi P, Verma IM (1988) Two adjacent promoter elements mediate nerve growth factor activation of the c-fos gene and bind distinct nuclear complexes. Proc Natl Acad Sci USA 85:94749478.

Volonte C, Ruckenstein A, Loeb DM, Greene LA (1989) Differential inhibition of nerve growth factor responses by purine analogues: correlation with inhibition of a nerve growth factor-activated protein kinase. J Cell Biol 109:2395-2403.

Vulliet PR, Hall FL, Mitchell JP, Hardie DG (1989) Identification of a novel proline-directed serine/treonine protein kinase in rat pheochromocytoma. J Biol Chem 264:16292-16298.

Wu DK, Maciac TA, De Vellis J (1988) Regulation of neuroblast proliferation by hormones and growth factors in chemically defined medium. J Cell Physiol 136:367-372.

Wuenschell CW, Mori N, Anderson DJ (1990) Analysis of SCG10 gene expression in transgenic mice reveals that neural specificity is achieved through selective derepression. Neuron 4:595-602.

Yamamoto KK, Gonzalez GA, Biggs WH, Montminy MR (1988) Phosphorylation-induced binding and transcriptional efficacy of nuclear factor CREB. Nature 334:494-498.

Yamamoto KK, Gonzalez GA, Menzel P, Rivier J, Montminy MR (1990) Characterization of a bipartite activator domain in transcription factor CREB. Cell 60:611-617. 